\title{
220STE BESTUURSVERGADERING,
}

\author{
GEHOUDEN 19 MAART 1881.
}

Tegenwoordig de heeren van Rappard (Voorzitter), Kniphorst (Penningmeester), van der Gon Netscher, Lammers van Toorenburg, Robidé van der Aa, Alting Mees, Juynboll, Meinsma, Niemann en Wijnmalen (Secretaris). Afwezig met kennisgeving de heeren van Goltstein, Quarles van Ufford en Humme.

De Voorzitter deelt mede dat van de heeren van Goltstein, Quarles van Ufford en Humme bericht is ontvangen, dat zij verhinderd zijn de vergadering bij te wonen, terwijl hij het nieuw benoemd Bestuurslid, den heer Alting Mees, welkom heet en hem de zorg voor de belangen van het Instituut aanbeveelt.

Hierna worden voorgelezen en goedgekeurd: $1^{\circ}$. de notulen van het verhandelde in de Bestuursvergadering van den 26 Februari $\mathrm{jl} ; 2^{\circ}$. de notulen van het verhandelde in de Algemeene Vergadering, op dienzelfden dag gehouden; en eindelijk $3^{\circ}$. de notulen van het verhandelde in de buitengewone Bestuursvergadering, na afloop der Algemeene Vergadering gehouden. Tevens wordt goedgekeurd de aanteekeningen van het verhandelde in de Algemeene Vergadering, voorloopig door het Bestuur vastgesteld, als naar gewoonte in de Bijdragen te doen drukken.

De Voorzitter deelt mede, dat zijn ingekomen:

a. eene missive van den heer van Goltstein houdende bericht van de aanneming zijner herbenoeming tot Ondervoorzitter.

b. eene missive van den heer H. C. Humme, houdende 
mededeeling van de aanneming zijner benoeming tot lid van het Bestuur.

c. eene gedrukte missive, bevattende kennisgeving van het overlijden van het lid, den heer mr. P. J. Bachiene.

d. missives van de heeren A. H. L. Badings, P. A. M. Boele van Hensbroek, mr. W. C. Borsius, P. R. Goudschaal, B. Heldring, dr. M. Th. Houtsma, mr. H. Hope Loudon, Prof. dr. K. Martin, W. J. Pahud de Mortanges, A. Pompe, Jhr. J. D. Six, mr. O. W. Star Numan, mr. J. W. Tydeman Jr., mr. S A. Vening Meinesz en J. Wüste, allen houdende mededeeling, dat zij de benoeming tot leden van het Instituut aannemen.

e. missives van de heeren F. A. van Braam Houckgeest, Jhr. Flugi van Aspermont, mr. A. Heijligers en Prof. dr. B. Symons, allen hun leedwezen te kennen gevende, datzij het lidmaatschap van het Instituut niet kunnen aanvaarden.

$f$. eindelijk, eene missive van den heer P. A. Tiele, te Utrecht, houdende bericht van de annvaarding zijner benoeming tot corresponderend lid van het Instituut.

Al deze missives, sub $a-f$ vermeld, worden voor kennisgeving aangenomen.

Door den Secretaris-Bibliothecaris wordt vervolgens mededeeling gedaan van de titels der sedert de vorige Vergadering ingekomen boekwerken, in verband waarmeê door hem wordt voorgelezen :

a. eene missive van den heer J. A. Vermeulen, President van de Onderwijzers-vereeniging, te Semarang, waarbij eenige in de verzameling van het Institunt ontbrekende jaargangen en nummers van het orgaan dier Vereeniging worden aangeboden. Hiervoor is bereids dank gezegd.

b. eene missive van de Smithsonian Institution, te Was hington, waarbij, onder toezending van de laatst verschenen Genootschapswerken, het verzoek wordt gedaan eenige mededeelingen te verstrekken omtrent de inrichting van het Instituut, de samenstelling van zijn bestuur, zijn ledental, zijne wetenschappelijke werkzaamheid, uitgaren en bibliotheek, met opgave voorts van hetgeen het Instituut in zijne verzameling bezit van de door de Smithsonian Institution achtereenvolgens uitgegeven werken, met name van de "Smithsonian contributions to knowledge" (in 4to) "Miscellaneous collec. 
lections" (in 80) en "Smithsonian Annual Reports" (in 80).

De Secretaris wordt gemachtigd aan het gedaan verzoek te voldoen.

Ter tafel wordt gebracht een schrijven, dd. 15 Januari 11., van den Commissaris van het Instituut te Batavia, den heer D. Gerth van Wijk, waarin hij zijn leedwezen te kennen geeft, door de tijdelijke, doch ongedacht langdurige afwezigheid van zijn ambtgenoot, mr. L. W. C. van den Berg, onder wien de stukken, op het Instituut betrekking hebbende, berusten, de gegevens te missen om eenige belangrijke mededeelingen toe te zenden. Onder toezegging van een nader antwoord van de zijde des heeren van den Berg, op het schrijven van den 20 Aug. 1l., bepaalt de heer Gerth van Wijk zich thans alleen $1^{\circ}$. tot de opgave van eenige namen van personen, aie zich hebben aangemeld om tot lid van het Instituut benoemd te worden; en $2^{\circ}$. tot de mededeeling, dat per mail, bij de toezending van dagbladen, tegelijk is verzonden eene bijdrage van den heer J. Habbema, te Fort de Kock, over het Menangkabausch, waarvan de opname in de Bijdragen van het Instituut aanbevolen wordt.

$\mathrm{Na}$ eenige gedachtenwisseling wordt besloten de benoeming van de opgegeven personen tot leden van het Instituut uit te stellen tot na de ontvangst van de nadere door Commissarissen toegezegde inlichtingen.

Wat voorts de bijdrage des heeren Habbema betreft, herinnert de Secretaris, dat zij reeds in de vorige Vergadering door hem ter tafel gebracht werd en in handen gesteld van de heeren Juynboll en Meinsma. Beide adviseeren geen bezwaar te hebben het voorstel te ondersteunen om de gemelde bijdrage in het tijdschrift te doen opnemen. Dienovereenkomstig wordt, zonder beraadslaging, besloten.

Van een en ander zal aan Commissarissen bericht worden gezonden.

Naar aanleiding van een door hem van den heer Tiele ontrangen schrijven, deelt de Secretaris mede, dat hem eerlang het laatste gedeelte zal geworden van de belangrijke studie over de Europeërs in den Maleischen Archipel. De heer Tiele is daarbij tot 1600 gevorderd, sedert welk tijdperk de Hollanders de hoofdrol gaan spelen; het trekt hem 
zeer aan zijne taak geleidelijk op dezelfde wijze, gelijk hij tot dusver gedaan heeft, te vervolgen; immers $z$. i. is dit nog niet geschied, slechts partiëel door den heer De Jonge, wiens werk evenwel een der hoofdbronnen zal moeten zijn. Afgescheiden echter van de vraag of zijne bezigheden en gezondheid het zullen toelaten zulk eene omvangrijke taak alsnog op zich te nemen, zou de heer Tiele gaarne het advies van het Bestuur van het Instituut omtrent zulk eene voortzetting van zijn arbeid vernemen.

$\mathrm{Na}$ eenige gedachtenwisseling wordt besloten, den heer Tiele te kennen te geven dat het Bestuur het ten zeerste zou betreuren, zoo hij aan zijne in de Bijdragen opgenomen studie nu reeds een einde makkte, daar eene voortzetting daarvan in het belang der historische wetenschap mag worden geacht.

Door het lid, den heer A. L. Van Hasselt, is een exemplaar toegezonden van een brief, door hem aan vier heeren Maleische taal-beoefenaars (de hh. D. Gerth van Wijk, J. L. van der Toorn, L. K. Harmsen en J. Habbema) gericht, waarin wordt aangedrongen op meer eenstemmigheid in de wijze van uitdrukking alvorens verder te gaan met het publiceeren van opstellen over Manangkabosch. Een afdruk van dien brief wordt ook aan het Instituut aangeboden, met verzoek zijn voorstel in overweging te nemen, en, mocht men zijne opvatting deelen, alsdan op de een of andere wijze in het openbaar te kennen te geven zulk eene overeen. stemming op prijs te stellen, en zooveel mogelijk het tot stand komen van zulk een taalkundig verdrag te helpen bevorderen. Mocht men soms noodig oordeelen bedoelden brief in zijn geheel af te drukken, het verlof daartoe wordt gaarne verleend.

Overeenkomstig het voorstel des Voorzitters wordt besloten de hehandeling van dit voorstel tot de volgende Vergadering te verdagen en de Bestuursleden Juyuboll en Meinsma uit te noodigen alsdan de Vergadering te willen voorlichten met hun praeadvies.

Door den heer Robidé van der Aa en den Secretaris worden, onder mededeeling van de van den heer Carl Bock ontvangen brieven, uitvoerige inlichtingen verstrekt omtrent den druk en de uitgave der reisverhalen van dien Reiziger. 
Daaruit blijkt, dat de reeds sedert langen tijd toegezegde nadere rapporten met de beschrijving der platen en enkele andere stukken ontvangen zijn; dat met de vertaling van een en ander onverwijld een begin is gemaakt; dat voorts een groot gedeelte van de vroeger ontvangen verslagen ter uitgave gereed is, met den druk waarvan men dan ook hereids is hegonnen; dat, eindelijk, aan het werk eene historische inleiding zal worden toegevoegd over Koetei en de betrekking van dit leenrijk tot de regeering van Neer landsch-Indië. Met het oog echter op het voornemen des heeren bock om zijne rapporten met de daarbij behoorende platen spoedig in het Engelsch uit te geven, terwijl het zeer gewenscht zou zijn dat die rapporten en platen, welke laatste geheel gerced zijn - - eerder hier te lande het licht zagen, wordt der Vergadering door den heer Robidé van der Aa en den Secretaris in overweging gegeven hen te machtigen de uitgave der rapporten in afleveringen te doen plaats hebben, waarvan de eerste tegen het einde van April of begin van Mei zou kunnen geschieden, vergezeld van eene portefeuille met de reeds gereed zijnde 30 platen en, zoo mogelijk ook, van eene schetskaart.

Overeenkomstig het voorstel des Voorzitters, wordt onder dankbetuiging voor de verstrekte inlichtingen, de gevraagde machtiging verleend.

Naar aanleiding van het reeds vroeger door den heer Juynboll aanbevolen denkbeeld eener aansporing tot onderzoek van de historische monumenten van den Indischen Archipel wordt de vraag overwogen, in welken vorm dit het gevoeglijkst ter kennis van het wetenschappelijk publiek en verdere belangstellenden zou kunnen worden gebracht. $\mathrm{Na}$ gedachtenwisseling vereenigt de Vergadering zich met eene daaromtrent door den heer Juijnboll ingediende nota en besluit zij haar te doen opnemen in de eerstvolgende aflevering der Bijdragen.

Ter verlichting van de vele en toenemende werkzaamheden, aan het Secretariaat en Bibliothecariaat verbonden, stelt de Secretaris voor, hem machtiging te verleenen tot de aanstelling van een gesalariëerden klerk, met ingang van 1 April a. s. Dienovereenkomstig wordt besloten. 
Door den Voorzitter wordt voorgesteld het lidmaatschap van het Instituut op te dragen aan den heer Jhr. mr. O. E. van Nispen, oud-resident van Batavia, thans hier ter stede gevestigd. Dienovereenkomstig wordt besloten.

Naar aanleiding eener opmerking van den heer Niemann omtrent het gemis van de oudere jaargangen der Javaansche almanakken in de bibliotheek van het Instituut, verklaart de Secretaris zich bereid te trachten die leemte aan te vullen.

Niets meer hierna aan de orde zijnde, wordt de Vergadering door den Voorzitter gesloten. 